\title{
Atmospheric photochemistry of aromatic hydrocarbons: OH budgets during SAPHIR chamber experiments
}

\author{
S. Nehr ${ }^{1, *}$, B. Bohn ${ }^{1}$, H.-P. Dorn ${ }^{1}$, H. Fuchs ${ }^{1}$, R. Häseler ${ }^{1}$, A. Hofzumahaus ${ }^{1}$, X. Li ${ }^{1}$, F. Rohrer ${ }^{1}$, R. Tillmann ${ }^{1}$, and \\ A. Wahner ${ }^{1}$ \\ ${ }^{1}$ Institut für Energie- und Klimaforschung, IEK-8: Troposphäre, Forschungszentrum Jülich GmbH, Jülich, Germany \\ *now at: Verein Deutscher Ingenieure e.V., Kommission Reinhaltung der Luft, Düsseldorf, Germany
}

Correspondence to: B. Bohn (b.bohn@fz-juelich.de)

Received: 28 January 2014 - Published in Atmos. Chem. Phys. Discuss.: 3 March 2014

Revised: 20 May 2014 - Accepted: 3 June 2014 - Published: 4 July 2014

\begin{abstract}
Current photochemical models developed to simulate the atmospheric degradation of aromatic hydrocarbons tend to underestimate $\mathrm{OH}$ radical concentrations. In order to analyse $\mathrm{OH}$ budgets, we performed experiments with benzene, toluene, $p$-xylene and 1,3,5-trimethylbenzene in the atmosphere simulation chamber SAPHIR. Experiments were conducted under low-NO conditions (typically $0.1-0.2 \mathrm{ppb}$ ) and high-NO conditions (typically 7-8 ppb), and starting concentrations of 6-250 ppb of aromatics, dependent on $\mathrm{OH}$ rate constants. For the $\mathrm{OH}$ budget analysis a steady-state approach was applied in which $\mathrm{OH}$ production and destruction rates $\left(P_{\mathrm{OH}}\right.$ and $\left.D_{\mathrm{OH}}\right)$ have to be equal. The $P_{\mathrm{OH}}$ were determined from measurements of $\mathrm{HO}_{2}, \mathrm{NO}, \mathrm{HONO}$, and $\mathrm{O}_{3}$ concentrations, considering $\mathrm{OH}$ formation by photolysis and recycling from $\mathrm{HO}_{2}$. The $D_{\mathrm{OH}}$ were calculated from measurements of the $\mathrm{OH}$ concentrations and total $\mathrm{OH}$ reactivities. The $\mathrm{OH}$ budgets were determined from $D_{\mathrm{OH}} / P_{\mathrm{OH}}$ ratios. The accuracy and reproducibility of the approach were assessed in several experiments using $\mathrm{CO}$ as a reference compound where an average ratio $D_{\mathrm{OH}} / P_{\mathrm{OH}}=1.13 \pm 0.19$ was obtained. In experiments with aromatics, these ratios ranged within 1.1-1.6 under low-NO conditions and 0.9-1.2 under high-NO conditions. The results indicate that $\mathrm{OH}$ budgets during photo-oxidation experiments with aromatics are balanced within experimental accuracies. Inclusion of a further, recently proposed $\mathrm{OH}$ production via $\mathrm{HO}_{2}+\mathrm{RO}_{2}$ reactions led to improvements under low-NO conditions but the differences were small and insignificant within the experimental errors.
\end{abstract}

\section{Introduction}

Large amounts of volatile organic compounds (VOCs) are released into the Earth's atmosphere from both biogenic and anthropogenic sources with an estimated global emission rate of the order of $10^{12} \mathrm{~kg}$ per year (Piccot et al., 1992; Arneth et al., 2011). Aromatic hydrocarbons like benzene, toluene, xylenes and trimethylbenzenes are among the most abundant organic trace constituents observed in the urban environment (Fortin et al., 2005; Johnson et al., 2010). Major emission sources of aromatics are vehicle exhaust, solvent usage and residential wood burning (Hawthorne et al., 1988; Niedojadlo et al., 2007). Once emitted to the atmosphere, organic compounds are oxidized photochemically and are then removed by wet or dry deposition.

The self-cleaning ability of the atmosphere mainly results from the presence of $\mathrm{OH}$ radicals that initiate the oxidation processes of most VOCs, including aromatics (Ehhalt, 1999). The predominant primary atmospheric $\mathrm{OH}$ source is the photolysis of $\mathrm{O}_{3}$ (Finlayson-Pitts and Pitts, 2000). At wavelengths below about $330 \mathrm{~nm}, \mathrm{O}_{3}$ is photolysed to electronically excited $\mathrm{O}\left({ }^{1} \mathrm{D}\right)$ that subsequently may react with water vapour to give $\mathrm{OH}$ :

$\mathrm{O}_{3}+h v \rightarrow \mathrm{O}\left({ }^{1} \mathrm{D}\right)+\mathrm{O}_{2} \quad \lambda<330 \mathrm{~nm}$

$\mathrm{O}\left({ }^{1} \mathrm{D}\right)+\mathrm{H}_{2} \mathrm{O} \rightarrow 2 \mathrm{OH}$.

Only a minor fraction of $\mathrm{O}\left({ }^{1} \mathrm{D}\right)$ reacts with $\mathrm{H}_{2} \mathrm{O}$, the remainder is deactivated by collisional quenching followed by a regeneration of $\mathrm{O}_{3}$. Photolysis of $\mathrm{HONO}$ at wavelengths below about $400 \mathrm{~nm}$ is another important $\mathrm{OH}$ source, especially 
close to the ground and in the morning hours (Kleffmann, 2007), but also in simulation chambers like SAPHIR (Rohrer et al., 2005):

$$
\mathrm{HONO}+h v \rightarrow \mathrm{OH}+\mathrm{NO} \quad \lambda<400 \mathrm{~nm} .
$$

These primary photolytic production processes are necessary but insufficient to maintain an effectual $\mathrm{OH}$ concentration, especially in the presence of high concentrations of VOCs. A regeneration of $\mathrm{OH}$ from $\mathrm{HO}_{2}$ radicals is therefore essential:

$\mathrm{HO}_{2}+\mathrm{NO} \rightarrow \mathrm{OH}+\mathrm{NO}_{2}$

$\mathrm{HO}_{2}+\mathrm{O}_{3} \rightarrow \mathrm{OH}+2 \mathrm{O}_{2}$

$\mathrm{HO}_{2}$ can be formed photolytically (e.g. from formaldehyde), directly following the initial $\mathrm{OH}+\mathrm{VOC}$ reactions (prompt $\left.\mathrm{HO}_{2}\right)$, or indirectly from organic peroxy radicals $\left(\mathrm{RO}_{2}\right)$ after another reaction step involving NO:

$$
\begin{aligned}
& \mathrm{OH}+\mathrm{VOC} \rightarrow \mathrm{RO}_{2} \\
& \mathrm{RO}_{2}+\mathrm{NO} \rightarrow \mathrm{RO}+\mathrm{NO}_{2} \\
& \mathrm{RO}+\mathrm{O}_{2} \rightarrow \mathrm{R}^{\prime} \mathrm{O}+\mathrm{HO}_{2} .
\end{aligned}
$$

Thus, the presence of $\mathrm{NO}$ leads to a propagation of the radical chain and counteracts terminating $\mathrm{HO}_{2}$ and $\mathrm{RO}_{2}$ self- and cross-reactions. NO itself is regenerated during daylight by $\mathrm{NO}_{2}$ photolysis that is accompanied by a net $\mathrm{O}_{3}$ production. Typically the NO Reaction (R4) is dominating while the $\mathrm{O}_{3}$ Reaction (R5) is of minor importance because of a very small rate constant. However, at too high concentrations of $\mathrm{NO}_{\mathrm{x}}$, $\mathrm{OH}$ concentrations decrease because of a terminating $\mathrm{OH}+$ $\mathrm{NO}_{2}$ reaction.

In contrast to this concept, recent field studies in areas characterized by high biogenic VOC and low NO concentrations revealed unexpectedly high levels of $\mathrm{OH}$ that could not be explained by model calculations. It was speculated that these discrepancies are explainable by so far unaccounted $\mathrm{OH}$ recycling processes, e.g. $\mathrm{OH}$ formation via $\mathrm{RO}_{2}+\mathrm{HO}_{2}$ reactions (Lelieveld et al., 2008), unimolecular decomposition reactions of $\mathrm{RO}_{2}$ radicals (Peeters et al., 2009; Crounse et al., 2011; Fuchs et al., 2013) and/or fast photolysis of hydroperoxide compounds (Wolfe et al., 2012). Alternatively, a generic mechanism assuming the presence of an unknown compound acting chemically similar as NO was postulated and utilized to quantify the missing rate of $\mathrm{OH}$ recycling (Hofzumahaus et al., 2009). Based on a steady-state approach for $\mathrm{OH}$, Hofzumahaus et al. (2009) compared the known production and destruction rates of $\mathrm{OH}$ by taking measured concentrations of $\mathrm{OH}, \mathrm{HO}_{2}, \mathrm{NO}$ and the total $\mathrm{OH}$ reactivity of ambient air. It was concluded that during a field campaign in the Pearl River Delta in southern China, the conventional $\mathrm{OH}$ recycling rate by $\mathrm{HO}_{2}+\mathrm{NO}$ was too small by a factor of three to explain the measured $\mathrm{OH}$ under low-NO conditions (Hofzumahaus et al., 2009; Lu et al., 2012).

In this work, a similar, widely model-independent approach to investigate $\mathrm{OH}$ budgets is used for the analysis of SAPHIR simulation chamber experiments with aromatic compounds. Aromatics contributed significantly to the $\mathrm{OH}$ reactivity during the measurements in the Pearl River Delta (Lou et al., 2010) and potential additional $\mathrm{OH}$ recycling from aromatics oxidation would therefore impact the $\mathrm{OH}$ budget. Previous chamber experiments with aromatics indeed showed unexpectedly high $\mathrm{OH}$ concentrations compared to model calculations (Bloss et al., 2005a). Moreover, recent laboratory work revealed high yields of prompt $\mathrm{HO}_{2}(\mathrm{Nehr}$ et al., 2011, 2012) and effective $\mathrm{OH}$ recycling in reactions of $\mathrm{HO}_{2}$ with aromatics-related peroxy radicals (Birdsall et al., 2010; Birdsall and Elrod, 2011):

$\mathrm{RO}_{2}+\mathrm{HO}_{2} \rightarrow \mathrm{RO}+\mathrm{O}_{2}+\mathrm{OH}$.

An $\mathrm{OH}$ budget investigation under the controlled conditions in SAPHIR was therefore performed with four selected monoaromatic compounds together with reference experiments with $\mathrm{CO}$ to evaluate the validity and the accuracy of the approach.

\section{Experimental}

The outdoor atmosphere simulation chamber SAPHIR at Forschungszentrum Jülich facilitates the investigation of photochemical processes under defined conditions (see Karl et al., 2004; Poppe et al., 2007). The SAPHIR chamber has a cylindrical shape ( $18 \mathrm{~m}$ length, $5 \mathrm{~m}$ diameter, $270 \mathrm{~m}^{3}$ volume). The chamber wall is a Teflon film that is held by a steel frame. The teflon film is chemically inert and transmits solar radiation without significant absorption (Bohn and Zilken, 2005). A shutter system allows for a rapid opening and closing of the chamber roof within about $60 \mathrm{~s}$.

\subsection{Analytical instrumentation}

SAPHIR is equipped with a comprehensive set of analytical instruments. Measurements of experimental boundary conditions include temperature (ultrasonic anemometer), pressure (capacitive gauge), replenishment flow rate (mass flow controller) and photolysis frequencies (spectroradiometer). Measurements of trace gas concentrations include volatile organic compounds (proton transfer reaction time of flight mass spectrometry, PTR-TOF-MS), HCHO (Hantzsch reaction), HONO (long path absorption photometry, LOPAP), $\mathrm{CO}$ (reduction gas analysis, RGA), $\mathrm{CO}_{2}, \mathrm{CH}_{4}, \mathrm{H}_{2} \mathrm{O}$ (cavity ring-down spectroscopy, CRDS), as well as $\mathrm{NO}, \mathrm{NO}_{2}$ and $\mathrm{O}_{3}$ (chemiluminescence, $\mathrm{CL}$ ). The reader is referred to previous publications for detailed information on the analytical instrumentation of SAPHIR (Wegener et al., 2007; Fuchs et al., 2010, 2012; Dorn et al., 2013; Fuchs et al., 2013, and references therein). 
Table 1. Properties of key instruments for the investigation of $\mathrm{OH}$ budgets during SAPHIR experiments.

\begin{tabular}{llrlr}
\hline \multirow{2}{*}{ Observable } & Method & $\begin{array}{r}\text { Time } \\
\text { resolution [s] }\end{array}$ & $1 \sigma$ & precision \\
\hline $\mathrm{OH}$ & Laser-induced fluorescence (LIF) & 47 & $0.3 \times 10^{6} \mathrm{~cm}^{-3}$ & {$[\%]$} \\
$\mathrm{HO}_{2}, \mathrm{RO}_{2}$ & Laser-induced fluorescence (LIF) & 47 & $1 \times 10^{7} \mathrm{~cm}^{-3}$ & 10 \\
$\mathrm{OH}$ & Differential optical absorption spectroscopy (DOAS) & 205 & $0.8 \times 10^{6} \mathrm{~cm}^{-3}$ & 6.5 \\
$k_{\mathrm{OH}}$ & Flash photolysis/Laser-induced fluorescence (FP/LIF) & 180 & $0.3 \mathrm{~s}^{-1}$ & 5 \\
$\mathrm{NO}$ & Chemiluminescence (CL) & 90 & $0.005 \mathrm{ppb}$ & 7 \\
\hline
\end{tabular}

${ }^{*} \mathrm{RO}_{2}$ interference effects not included, see text.

Table 1 provides an overview of the key instruments for this study and their performances. Briefly, the detection of $\mathrm{OH}, \mathrm{HO}_{\mathrm{x}}$ ( sum of $\mathrm{OH}$ and $\mathrm{HO}_{2}$ ) and $\mathrm{RO}_{\mathrm{x}}$ (sum of $\mathrm{OH}, \mathrm{HO}_{2}$ and $\mathrm{RO}_{2}$ ) was performed by laser-induced fluorescence (LIF) spectroscopy (Holland et al., 2003; Fuchs et al., 2008, 2011). From these measurements, concentrations of $\mathrm{HO}_{2}$ and $\mathrm{RO}_{2}$ radicals were determined. Moreover, differential optical absorption spectroscopy (DOAS) (Dorn et al., 1995; Schlosser et al., 2007, 2009) was employed for the measurement of $\mathrm{OH}$ radical concentrations.

The total $\mathrm{OH}$ reactivity $k_{\mathrm{OH}}$, which is equivalent to the inverse atmospheric $\mathrm{OH}$ lifetime, was measured by the flash photolysis/laser-induced fluorescence (FP/LIF) technique that was first realized by Calpini et al. (1999) and later by Sadanaga et al. (2004). $k_{\mathrm{OH}}$ is a pseudo-first-order rate constant given by the following expression:

$k_{\mathrm{OH}}=\sum_{i} k_{\mathrm{X}_{i}+\mathrm{OH}}\left[\mathrm{X}_{i}\right]$

where $\left[\mathrm{X}_{i}\right]$ denotes the concentration of a reactive trace constituent and $k_{\mathrm{X}_{i}+\mathrm{OH}}$ is the respective second-order rate constant. The instrument used in this work at SAPHIR was deployed in previous field campaigns and is described in detail elsewhere (Hofzumahaus et al., 2009; Lou et al., 2010). The reported $k_{\mathrm{OH}}$ were corrected for wall losses within the instrument that account for loss rate coefficients of typically $1.5 \mathrm{~s}^{-1}$ (Nehr et al., 2012).

\subsection{Materials}

The SAPHIR chamber was operated with highly purified synthetic air made from liquid $\mathrm{N}_{2}$ and $\mathrm{O}_{2}$ ( $99.9999 \%$, Linde). Benzene ( $99.8 \%$, Merck), toluene (99.9\%, Merck), $p$-xylene (99.8\%, BDH Prolabo), and 1,3,5-trimethylbenzene (1,3,5-TMB; 99.0\%, Sigma Aldrich) were used as purchased. For experiments with elevated NO concentrations a mixture of $600 \mathrm{ppm}$ of $\mathrm{NO}(99.5 \%$, Messer Griesheim) in $\mathrm{N}_{2}(99.999 \%)$ was added to the chamber. CO was used in pure form (99.997\%, Messer Griesheim). Gases were introduced into the chamber using calibrated mass flow controllers. Liquids were injected by microlitre syringes via a heated injection port.

\subsection{Experiment procedure}

The sequence of a typical SAPHIR experiment is shown in Fig. 1, taking the photo-oxidation of 1,3,5-TMB performed on 17 June 2010 as an example. All experiments were started after the chamber was flushed overnight with high-purity dry synthetic air to purge trace gases below the limits of detection. A fan was used to assure homogeneous mixing. In the morning, the clean chamber was humidified by flushing ultrapure water vapour (Milli-Q) from a vaporizer with a high flow of zero air into the chamber. Afterwards, the shutter system was opened and the chamber was exposed to sunlight. Usually, no other trace gases were then added for a period of about two hours. During this so-called zero air period, HONO was formed photolytically at the chamber walls dependent on humidity and UV radiation (Rohrer et al., 2005). Relative humidities were around $40 \%$ during the illumination periods. Photolysis of HONO is the major primary source of $\mathrm{OH}$ radicals in SAPHIR and therefore $\mathrm{OH}$ (and $\mathrm{NO})$ concentrations were found to increase during this period. Moreover, the background $\mathrm{OH}$ reactivity that typically builds up within SAPHIR without addition of any reactants, slowly rose to about $2 \mathrm{~s}^{-1}$. Subsequently, the compound of interest ( $\mathrm{CO}$ or an aromatic hydrocarbon) was injected into the chamber. The example in Fig. 1 shows an injection of about $6 \mathrm{ppb}$ of 1,3,5-TMB as reproduced by PTR-TOF-MS and the $\mathrm{OH}$ reactivity instrument. The resulting concentration of $\mathrm{OH}$ radicals in SAPHIR depended on the concentrations of $\mathrm{OH}$ reactants and was further modulated by solar radiation. The initial aromatics concentrations were chosen dependent on the $\mathrm{OH}+$ aromatics rate constants to result in starting $\mathrm{OH}$ reactivities of about $10 \mathrm{~s}^{-1}$. This ensured that the total reactivity was dominated by the aromatic compound while it was still low enough to allow the detection of $\mathrm{OH}$ at good signal-to-noise ratios. After 6-8 h of illumination the chamber shutter system was closed. Experiments with aromatics were performed under low-NO (typically $0.1-0.2 \mathrm{ppb}$ after injection of aromatics) and high-NO (7-8 ppb) conditions. In the case of high-NO experiments, $\mathrm{NO}$ was injected 30 min prior to the addition of the aromatic. For low-NO experiments the source of NO was photolysis of HONO. Table 2 provides an overview of all SAPHIR experiments with aromatics utilized in this work. 


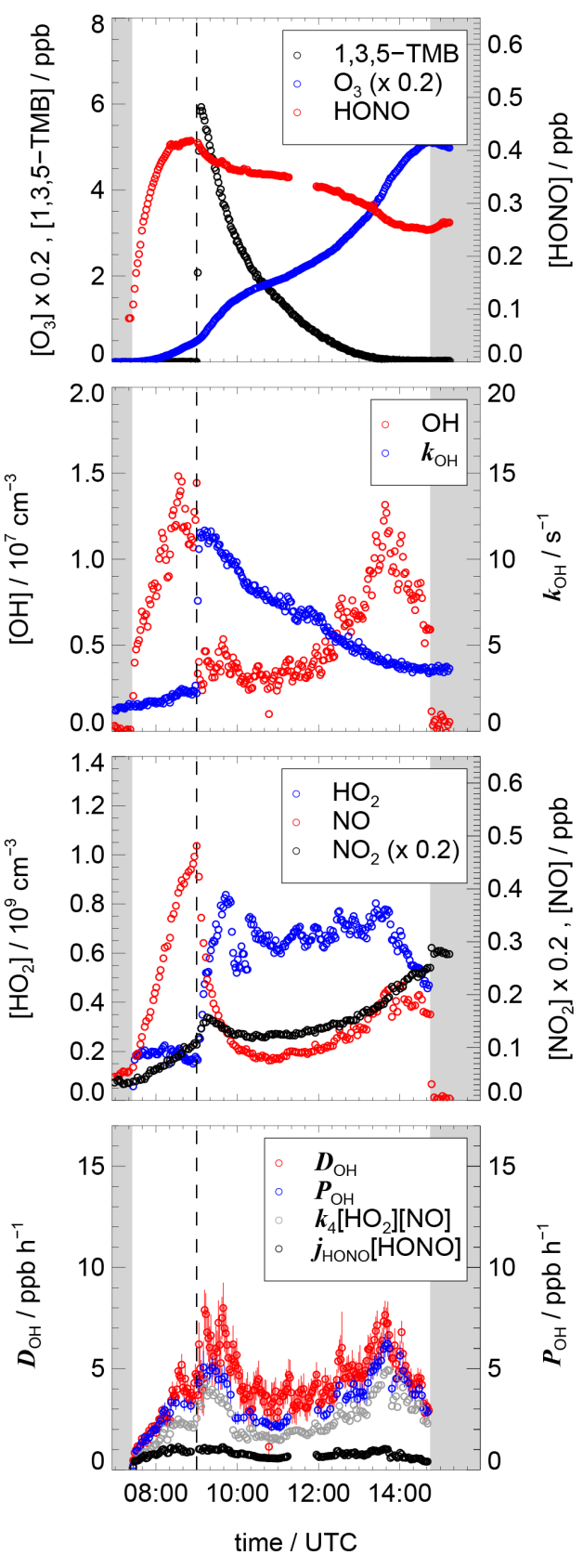

Figure 1. Measurements of selected quantities performed during a low-NO SAPHIR experiment with 1,3,5-TMB on 17 June 2010. Grey shaded areas indicate time periods when the chamber roof was closed. Formation of HONO, the major OH precursor in SAPHIR, was observed by LOPAP just after the humidified chamber was exposed to sunlight (red points, upper panel). The injection of 1,3,5TMB, marked by the vertical dashed line, was observed by PTRTOF-MS (black points, upper panel) and the $\mathrm{OH}$ reactivity instrument (blue points, second panel). $\mathrm{OH}$ and $\mathrm{NO}$ rapidly decreased whereas $\mathrm{HO}_{2}$ increased after the 1,3,5-TMB addition (middle panels). Diurnal profiles of $P_{\mathrm{OH}}$ and $D_{\mathrm{OH}}$ (lower panel) were calculated according to Eqs. (2) and (3). Other data in the lower panel show the main terms contributing to $P_{\mathrm{OH}}$.

\section{Data analysis and results}

The $\mathrm{OH}$ production rate $P_{\mathrm{OH}}$ resulting from Reactions (R1)(R5) is given by the following equation:

$$
\begin{aligned}
P_{\mathrm{OH}} & =j_{\mathrm{O}\left({ }^{1} \mathrm{D}\right)}\left[\mathrm{O}_{3}\right] \times 2 f_{\mathrm{OH}}+j_{\mathrm{HONO}}[\mathrm{HONO}] \\
& +k_{4}\left[\mathrm{HO}_{2}\right][\mathrm{NO}]+k_{5}\left[\mathrm{HO}_{2}\right]\left[\mathrm{O}_{3}\right]
\end{aligned}
$$

where $j_{\mathrm{O}\left({ }^{1} \mathrm{D}\right)}$ and $j_{\mathrm{HONO}}$ are the photolysis frequencies of Reactions (R1) and (R3), respectively, and $f_{\mathrm{OH}}$ denotes the fraction of $\mathrm{O}\left({ }^{1} \mathrm{D}\right)$ that reacts with $\mathrm{H}_{2} \mathrm{O}$ according to Reaction (R2). For the calculation of $P_{\mathrm{OH}}$, measured $j_{\mathrm{O}\left({ }^{1} \mathrm{D}\right)}$ and $j_{\mathrm{HONO}}$ were used, and rate constants $k_{4}$ and $k_{5}$ from recent recommendations: $k_{4}=3.45 \times 10^{-12} \mathrm{~cm}^{3} \mathrm{~s}^{-1} \times \exp (270 \mathrm{~K} / T), k_{5}=$ $2.03 \times 10^{-16} \mathrm{~cm}^{3} \mathrm{~s}^{-1} \times(T / 300 \mathrm{~K})^{4.57} \times \exp (693 \mathrm{~K} / T)(\mathrm{IU}-$ $\mathrm{PAC}, 2013)$. The $f_{\mathrm{OH}}$ typically were around 0.1 and were calculated using measured water vapour concentrations and recommend rate constants of $\mathrm{O}\left({ }^{1} \mathrm{D}\right)$ reactions (IUPAC, 2013).

It turned out that under all conditions $P_{\mathrm{OH}}$ was dominated by the NO Reaction (R4). The second most important $\mathrm{OH}$ source was photolysis of HONO, the contribution of which is shown in the lower panel of Fig. 1 as an example. It should be noted that in some experiments where HONO measurements were not available (Table 2) its concentration was estimated from the resulting $\mathrm{OH}$ concentration during the zero air period based on a parameterization of the HONO production rate in the chamber (Rohrer et al., 2005). Compared to $\mathrm{HONO}$ photolysis, $\mathrm{OH}$ production rates by $\mathrm{O}_{3}$ photolysis and the $\mathrm{O}_{3}$ Reaction (R5) are almost negligible under the experimental conditions employed, i.e. $\left[\mathrm{O}_{3}\right]<20 \mathrm{ppb}(<50 \mathrm{ppb}$ for some $\mathrm{CO}$ experiments).

The $\mathrm{OH}$ destruction rate $D_{\mathrm{OH}}$ is given by the product of the total $\mathrm{OH}$ reactivity and the $\mathrm{OH}$ concentration:

$D_{\mathrm{OH}}=k_{\mathrm{OH}}[\mathrm{OH}]$.

The $D_{\mathrm{OH}}$ can be calculated from only two measurements because all chemical $\mathrm{OH}$ losses are accounted for by the measurements of $k_{\mathrm{OH}}$. In contrast, unaccounted $\mathrm{OH}$ recycling processes and/or primary $\mathrm{OH}$ sources might be missed in $P_{\mathrm{OH}}$ calculated by Eq. (2). In any case, for a short-lived species like $\mathrm{OH}$, the steady-state approximation applies under the conditions of SAPHIR experiments:

$\frac{\mathrm{d}[\mathrm{OH}]}{\mathrm{d} t}=P_{\mathrm{OH}}-D_{\mathrm{OH}} \approx 0$.

Thus, ideally also the calculated $P_{\mathrm{OH}}$ of Eq. (2) should be balanced by $D_{\mathrm{OH}}$. This analysis is independent of mechanistic details and model simulations. The only exceptions are the $\mathrm{HO}_{2}$ data that were corrected for interferences caused by specific organic peroxy radicals (Nehr et al., 2011; Fuchs et al., 2011). However, these corrections were minor, $<20 \%$ in 2010 and $<5 \%$ in 2011, after technical modifications of the LIF instrument that were made before the 2011 experiments (Fuchs et al., 2011). More details on this correction can be found in the Appendix. 
Table 2. Compilation of SAPHIR experiments with starting concentrations of aromatic hydrocarbons ([aromatic $]_{0}$ ). These concentrations were calculated from the initial increase of $k_{\mathrm{OH}}$ upon addition of reactants using $\mathrm{OH}$ rate constants from $\mathrm{MCMv3.2;} \mathrm{[NO}]_{\max }$ denotes peak NO concentration during the experiments. Temperatures are mean values covering the experiment periods after injection of aromatics. Error bars correspond to minimum and maximum temperatures.

\begin{tabular}{lccc}
\hline date & $\begin{array}{c}\text { [aromatic }]_{0} \\
{[\mathrm{ppb}]}\end{array}$ & $\begin{array}{c}{[\mathrm{NO}]_{\max }} \\
{[\mathrm{ppb}]}\end{array}$ & $T[\mathrm{~K}]$ \\
\hline benzene & & & \\
\hline 7 Jun 2010 & 230 & 0.75 & $299 \pm 2$ \\
23 Jun 2010 & 235 & 0.55 & $303 \pm 3$ \\
1 Aug 2011 & 250 & 0.20 & $299 \pm 5$ \\
8 Jun 2010 & 235 & $7.6^{\mathrm{a}}$ & $297 \pm 3$ \\
25 Jun 2010 & 215 & $7.6^{\mathrm{a}}$ & $304 \pm 2$ \\
\hline toluene & & & \\
\hline 5 Jul 2010 & 65 & 0.46 & $300 \pm 4$ \\
4 Aug 2011 & 107 & 0.27 & $305 \pm 4$ \\
13 Jun 2010 & 60 & $7.1^{\mathrm{a}}$ & $297 \pm 3$ \\
\hline p-xylene & & & \\
\hline 14 Jun 2010 & 26 & 0.35 & $301 \pm 3$ \\
2 Jul 2010 & 26 & 0.35 & $311 \pm 3$ \\
7 Aug 2011 & 29 & 0.35 & $298 \pm 2$ \\
16 Jun 2010 & 24 & $6.9^{\mathrm{a}}$ & $299 \pm 3$ \\
30 Jun 2010 & 24 & $7.1^{\mathrm{a}}$ & $308 \pm 2$ \\
\hline 1,3,5-TMB & & & \\
\hline 17 Jun 2010 & 6.0 & 0.48 & $298 \pm 3$ \\
1 Jul 2010 & 6.5 & 0.45 & $308 \pm 3$ \\
10 Aug 2011 & 7.2 & 0.26 & $298 \pm 4$ \\
21 Jun 2010 & 6.0 & $7.2^{\mathrm{a}}$ & $295 \pm 1$ \\
28 Jun 2010 & 6.5 & $7.6^{\mathrm{a}}$ & $308 \pm 1$ \\
\hline
\end{tabular}

${ }^{a}$ High NO experiment. ${ }^{b}$ No HONO measurements available.

The closure of the $\mathrm{OH}$ budget was investigated by consulting mean $D_{\mathrm{OH}} / P_{\mathrm{OH}}$ ratios and their standard deviations for the different experiments. For this, all experimental data were synchronized to the time grid of the instrument with the lowest time resolution (either the $\mathrm{OH}$ reactivity instrument during experiments in 2010 or the DOAS instrument during experiments in 2011). For the calculation of the mean ratios, data points were weighted according to the errors for $D_{\mathrm{OH}}$ and $P_{\mathrm{OH}}$ resulting from contributions of all measured quantities using error propagation (Table 1).

A total of 13 experiments performed with $\mathrm{CO}$ in 2010 and 2011 were evaluated as reference experiments. Some of these experiments were dedicated to investigations of compounds other than aromatics where after an about 2-h CO reference period the compound of interest was injected. In these cases only the $\mathrm{CO}$ periods were taken into account. In other

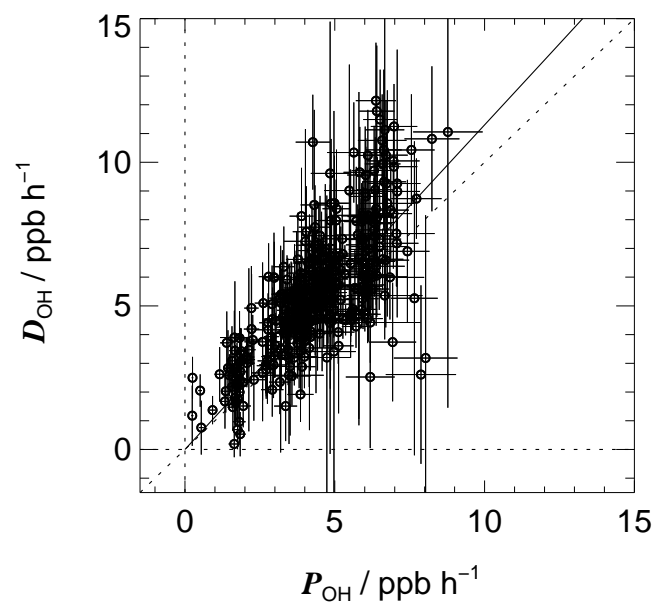

Figure 2. Correlation of $\mathrm{OH}$ destruction rates $\left(D_{\mathrm{OH}}\right)$ and production rates $\left(P_{\mathrm{OH}}\right)$ from all SAPHIR experiments with $\mathrm{CO}$ in 2010 and 2011. The solid line corresponds to a mean ratio of 1.13 , the dashed line indicates a $1: 1$ ratio. The total number of data points is 776 .

experiments several injections of $\mathrm{CO}$ were made to cover a wider range of $k_{\mathrm{OH}}$. CO was selected as a reference compound because its photochemistry is comparatively simple. It is unreactive towards all gas-phase species except $\mathrm{OH}$ and the only known product of this reaction is $\mathrm{HO}_{2}$ under the conditions employed. The average of the mean ratios $D_{\mathrm{OH}} / P_{\mathrm{OH}}$ obtained in the reference experiments was $1.13 \pm 0.19$. The 0.13 deviation from unity reflects the accuracy of the experimental approach. This deviation is well within the accuracy of the experimental input data and consequently the $\mathrm{OH}$ budget was closed for the $\mathrm{CO}$ experiments. The standard deviation of \pm 0.19 reflects the reproducibility of single experiments. All data obtained in $\mathrm{CO}$ experiments are collected in Fig. 2.

The results obtained with the different aromatic compounds are listed in Table 3 and examples of plots of $D_{\mathrm{OH}}$ as a function of $P_{\mathrm{OH}}$ under low- and high-NO conditions are shown in Figs. 3 and 4. The mean ratios $D_{\mathrm{OH}} / P_{\mathrm{OH}}$ ranged between 0.9 and 1.6 and were again mostly greater than unity. No trend was observed for the homologous series of aromatic compounds but low-NO experiments tended to give greater ratios (1.1-1.6) than high-NO experiments (0.9-1.2). Overall, considering the result of the $\mathrm{CO}$ reference experiments and experimental errors, $\mathrm{OH}$ budgets for all aromatics compounds are regarded as closed.

In order to test the potential influence of the recently proposed OH recycling by Reaction (R9), Eq. (2) was extended accordingly:

$P_{\mathrm{OH}}^{*}=P_{\mathrm{OH}}+k_{9}\left[\mathrm{HO}_{2}\right]\left[\mathrm{RO}_{2}\right]$

Estimates of the rate constant of Reaction (R9) were taken from the literature $\left(k_{9}=1 \times 10^{-11} \mathrm{~cm}^{3} \mathrm{~s}^{-1}\right.$, Birdsall et al., 2010). Because the $\mathrm{RO}_{2}$ measurements cannot distinguish between different species, the measured total $\mathrm{RO}_{2}$ 
concentrations and the same rate constant $k_{9}$ were used for the calculations. Inclusion of the additional term in Eq. (5) led to somewhat smaller ratios, in particular under low-NO conditions (see right-hand side of Table 3 for a direct comparison). However, overall the differences between $P_{\mathrm{OH}}^{*}$ and $P_{\mathrm{OH}}$ were small and merely in the range of experimental errors.

\section{Discussion}

The results listed in Table 3 show that the $\mathrm{OH}$ budgets during the $\mathrm{OH}$-initiated degradations of aromatic compounds were reasonably balanced within experimental errors for all investigated compounds. No clear trend was observed in the $\mathrm{OH}$ budget analysis for the homologous series of aromatic compounds. Although the degradation mechanism of all aromatics is similar, this result is noteworthy. Because the $\mathrm{OH}$ rate constants increase with the degree of methylation (Calvert et al., 2002), the employed initial concentrations of aromatics were very different, e.g. about $250 \mathrm{ppb}$ of benzene and $6 \mathrm{ppb}$ of 1,3,5-TMB. Accordingly, the fractions of the aromatics that were degraded at the end of the experiments differed strongly. While 1,3,5-TMB was completely consumed and $k_{\mathrm{OH}}$ decreased monotonically during the course of the experiment, this was not the case for benzene where only a minor fraction was lost and $k_{\mathrm{OH}}$ even increased because of more reactive secondary products. Despite these differences, in the temporal evolution of the experiments, no differences in the $\mathrm{OH}$ budget analyses were found. This implies that the results apply in the presence of primary and secondary $\mathrm{OH}$ reactants that emerge in aromatic degradation processes.

All results presented in Table 3 are based on $\mathrm{OH}$ LIF data that were available in 2010 and 2011. Using OH LIF or DOAS measurements made no difference in the $\mathrm{OH}$ budget analysis which is consistent with previous experiments in SAPHIR where excellent agreement of the two $\mathrm{OH}$ detection techniques was demonstrated under various experimental conditions (Schlosser et al., 2007, 2009; Fuchs et al., 2012).

The agreement between $P_{\mathrm{OH}}$ and $D_{\mathrm{OH}}$ was slightly better at high NO concentrations. However, this difference should be treated with caution considering the experimental uncertainties and the fact that $\mathrm{OH}$ destruction and production rates were greater by a factor of about four under high-NO conditions, mainly caused by greater $\mathrm{OH}$ and $\mathrm{NO}$ concentrations. Possible reasons for these discrepancies are measurement artefacts and additional $\mathrm{OH}$ recycling processes. $\mathrm{Re}$ garding the NO measurements, no problems are expected during low and high NO conditions because both concentration ranges were covered by regular calibrations using test gases. $\mathrm{HO}_{2}$ concentrations were comparable during high and low $\mathrm{NO}$ conditions because $\mathrm{HO}_{2}$ formation and destruction rates were both increased at increased NO. The same applies to $\mathrm{RO}_{2}$ concentrations and associated potential difficulties
Table 3. Analysis of $\mathrm{OH}$ budgets during SAPHIR experiments. Means and standard deviations of the ratios $D_{\mathrm{OH}} / P_{\mathrm{OH}}$ and $D_{\mathrm{OH}} / P_{\mathrm{OH}}^{*}$ calculated from measurements according to Eqs. (2) and (5), respectively. The data evaluation was restricted to time periods where the chamber was illuminated and aromatic $\mathrm{OH}$ reactants were present. $N$ denotes the number of data points.

\begin{tabular}{lccl}
\hline Date & $N$ & $D_{\mathrm{OH}} / P_{\mathrm{OH}}$ & $D_{\mathrm{OH}} / P_{\mathrm{OH}}^{*}$ \\
\hline Benzene & & & \\
\hline 7 Jun 2010 & 98 & $1.34 \pm 0.32$ & $1.28 \pm 0.29$ \\
23 Jun 2010 & 118 & $1.32 \pm 0.37$ & $1.22 \pm 0.33$ \\
1 Aug 2011 & 51 & $1.48 \pm 0.31$ & $1.44 \pm 0.29$ \\
8 Jun 2010* & 105 & $0.92 \pm 0.22$ & $0.91 \pm 0.22$ \\
25 Jun 2010* & 101 & $0.92 \pm 0.60$ & $0.90 \pm 0.56$ \\
\hline Toluene & & & \\
\hline 5 Jul 2010 & 107 & $1.42 \pm 0.29$ & $1.14 \pm 0.22$ \\
4 Aug 2011 & 35 & $1.56 \pm 0.68$ & $1.37 \pm 0.49$ \\
13 Jun 2010* & 53 & $1.17 \pm 0.34$ & $1.01 \pm 0.20$ \\
\hline p-xylene & & & \\
\hline 14 Jun 2010 & 71 & $1.60 \pm 0.35$ & $1.29 \pm 0.29$ \\
2 Jul 2010 & 78 & $1.52 \pm 0.37$ & $1.09 \pm 0.25$ \\
7 Aug 2011 & 15 & $1.59 \pm 0.61$ & $1.44 \pm 0.51$ \\
16 Jun 2010* & 53 & $1.12 \pm 0.31$ & $1.01 \pm 0.20$ \\
30 Jun 2010* & 50 & $1.05 \pm 0.47$ & $0.89 \pm 0.17$ \\
\hline 1,3,5-TMB & & & \\
\hline 17 Jun 2010 & 68 & $1.23 \pm 0.26$ & $1.07 \pm 0.18$ \\
1 Jul 2010 & 52 & $1.09 \pm 0.18$ & $0.69 \pm 0.13$ \\
10 Aug 2011 & 41 & $1.30 \pm 0.40$ & $1.02 \pm 0.20$ \\
21 Jun 2010* & 67 & $1.04 \pm 0.22$ & $1.01 \pm 0.19$ \\
28 Jun 2010* & 12 & $1.11 \pm 0.11$ & $0.99 \pm 0.10$ \\
\hline
\end{tabular}

* High-NO experiment.

regarding $\mathrm{RO}_{2}-\mathrm{HO}_{2}$ interferences (see Appendix). $k_{\mathrm{OH}}$ was also similar at high and low NO conditions and recycling of $\mathrm{OH}$ from $\mathrm{HO}_{2}$ was too slow at high $\mathrm{NO}$ to influence the $k_{\mathrm{OH}}$ measurements. An unaccounted primary $\mathrm{OH}$ source that is specific for SAPHIR is also unlikely because that would have its greatest effect during the zero air periods when the $\mathrm{OH}$ budget was closed (red points in Figs. 3 and 4). However, after addition of an $\mathrm{OH}$ reactant under low $\mathrm{NO}$ conditions, $\mathrm{OH}$ drops strongly making these measurements more challenging. An unaccounted offset in the $\mathrm{OH}$ measurements could produce the observed mismatch between $\mathrm{OH}$ production and destruction rates, independent of the nature of the added reactant. That could explain why the ratios for $\mathrm{CO}$ and aromatics were mostly greater than unity under low NO conditions. In previous LIF-DOAS comparisons no such offset in the $\mathrm{OH}$ LIF measurements was found, as mentioned above. But it has to be taken into account that DOAS measurements are also more difficult at low $\mathrm{OH}$ concentrations. 

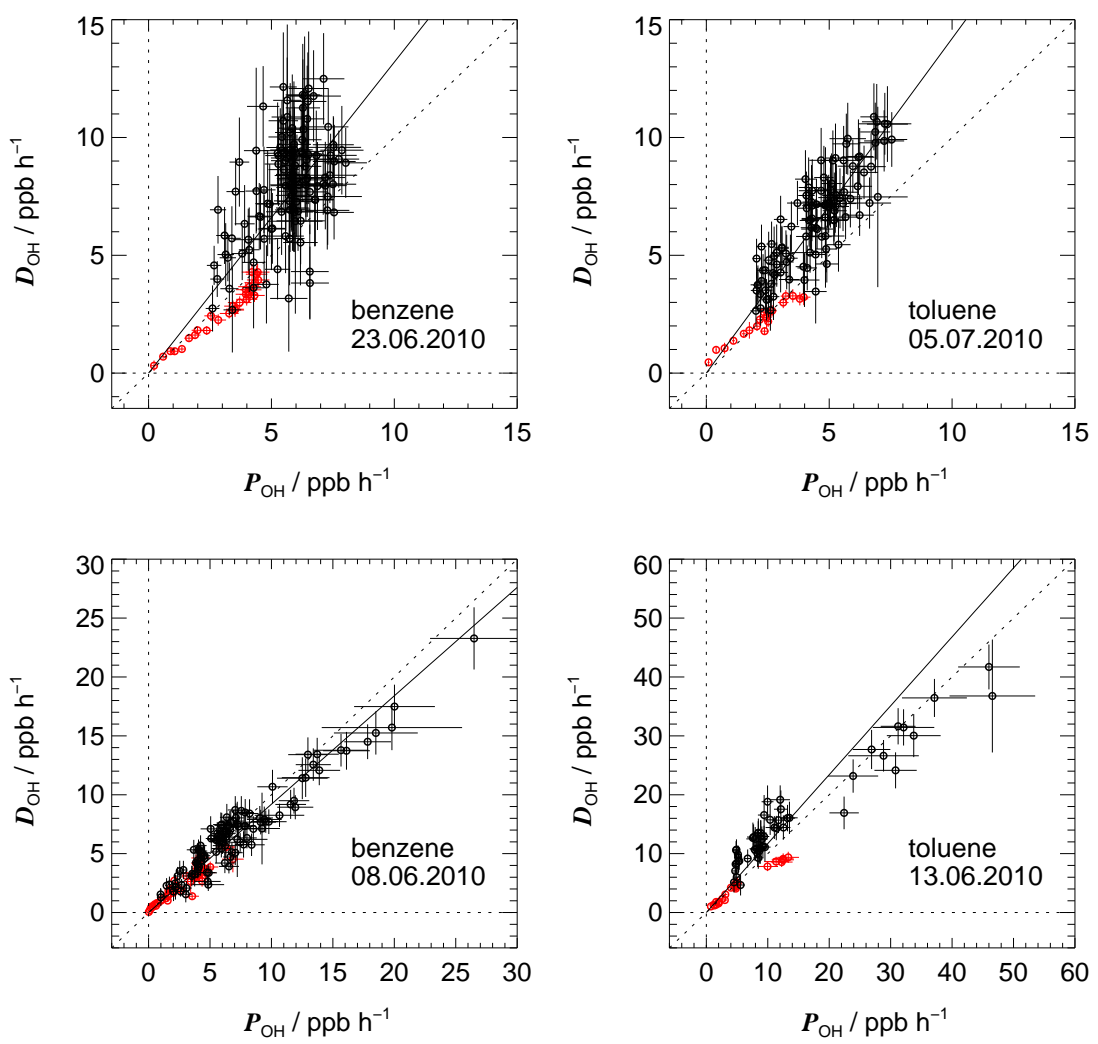

Figure 3. Correlation of $\mathrm{OH}$ destruction rates $\left(D_{\mathrm{OH}}\right)$ and production rates $\left(P_{\mathrm{OH}}\right)$ for SAPHIR experiments in 2010 under low-NO conditions (upper panels) and high-NO conditions (lower panels). Black and red data points indicate different periods of the experiments. Red: zero air period; Black: after the injection of aromatics. The solid lines correspond to the mean ratios listed in the third column of Table 3 ( $P_{\mathrm{OH}}$ calculated by Eq. 2), dashed lines are $1: 1$ lines.

The differences of the ratios could also be caused by additional $\mathrm{OH}$ recycling via $\mathrm{HO}_{2}+\mathrm{RO}_{2}$ reactions that gain importance under low-NO conditions. Such radical-radical reactions that are usually thought to produce non-radical products can lead to enhanced $\mathrm{OH}$ recycling as shown by recent laboratory studies for reactions of carbonyl-containing $\mathrm{RO}_{2}$ radicals with $\mathrm{HO}_{2}$ (Hasson et al., 2004, 2012; Jenkin et al., 2007, 2008, 2010; Dillon and Crowley, 2008; Groß et al., 2014). Recently also $\mathrm{OH}$ formation for the reaction of $\mathrm{HO}_{2}$ with bicyclic peroxy radicals from aromatic precursors was proposed with a rate constant $k_{9}$ as used in the previous section. This rate constant corresponds to an $\mathrm{OH}$ yield of about 0.5 (Birdsall et al., 2010; Birdsall and Elrod, 2011) in agreement with a conservative upper limit of 0.5 estimated previously for bicyclic peroxy radicals from benzene (Jenkin et al., 2007). However, this upper limit may have to be scaled down further in view of recent results (Jenkin, 2014) and consequently the importance of this $\mathrm{OH}$ source is highly speculative. In our present work, the influence of the $\mathrm{HO}_{2}+\mathrm{RO}_{2}$ reactions could only roughly be quantified in $P_{\mathrm{OH}}^{*}$ by using the measured total $\mathrm{RO}_{2}$ concentrations and the same estimated rate constant $k_{9}$ from the literature. Despite these uncertainties the small effects were found to have the right magnitude and to go in the right direction. Our data are therefore not in contradiction with the proposed additional $\mathrm{OH}$ recycling but cannot confirm it quantitatively. In any case, $\mathrm{HO}_{2}+\mathrm{RO}_{2}$ reactions played a minor role for the $\mathrm{OH}$ budget even under the low-NO conditions of this work.

Current explicit degradation schemes of the Master Chemical Mechanism (MCMv3.2) underestimated $\mathrm{OH}$ radical concentrations in previous environmental chamber studies of aromatic compounds (Bloss et al., 2005a, b). This mismatch between simulated $\mathrm{OH}$ concentrations and those indirectly inferred from the decay rates of aromatic reactants was attributed to potentially missing $\mathrm{OH}$ production processes (Wagner et al., 2003). Our straightforward experimental investigation of the radical balance however suggests that so far unaccounted $\mathrm{OH}$ production reactions are not likely to be a reason for this $\mathrm{OH}$ underprediction. Rather, there seems to be an overestimation of $\mathrm{OH}$ reactivities of secondary products and an underestimation of peroxy radical concentrations in these model simulations, as will be discussed in more detail in a companion publication (Nehr et al., 2014).

The high and low NO concentrations employed in this work roughly corresponded to the conditions encountered in the Pearl River Delta field study during morning and 

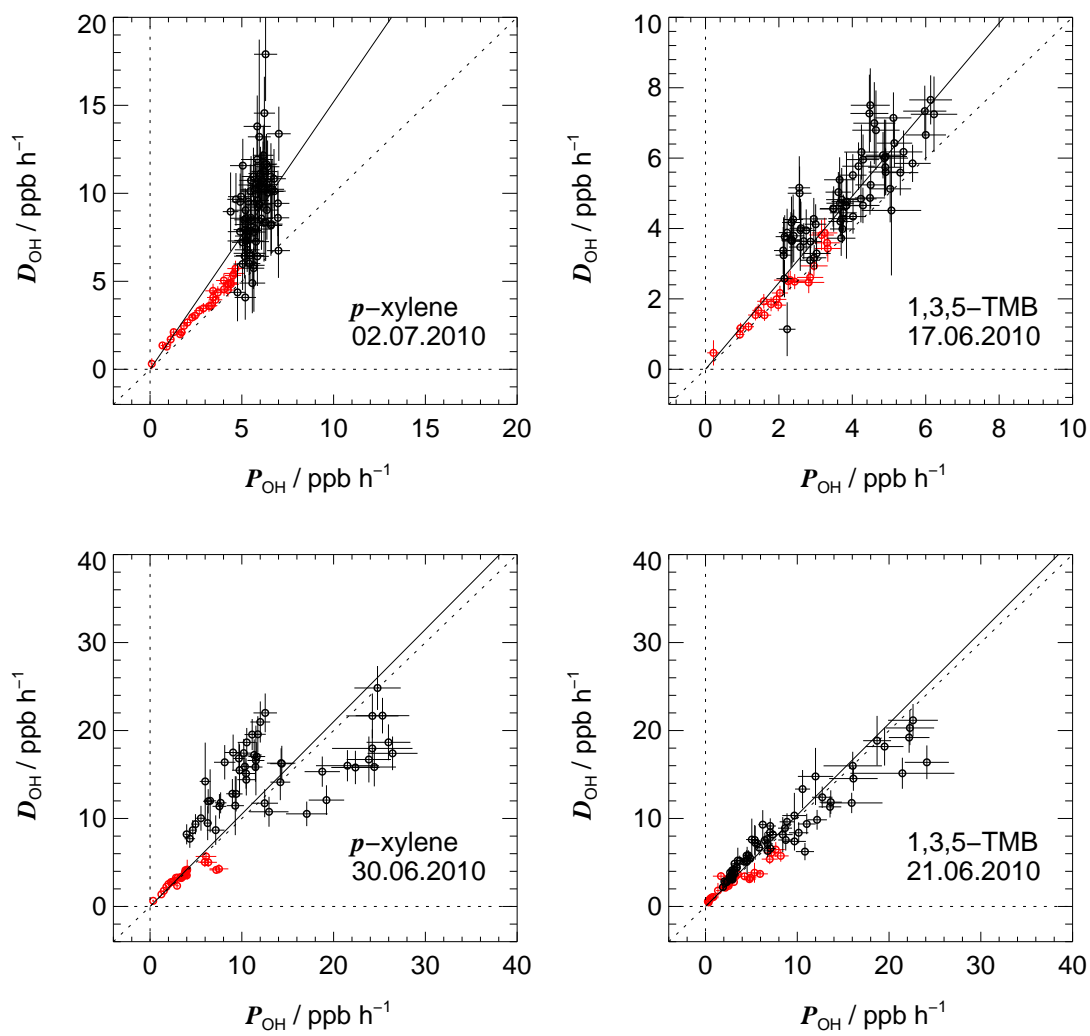

Figure 4. Correlation of $\mathrm{OH}$ destruction rates $\left(D_{\mathrm{OH}}\right)$ and production rates $\left(P_{\mathrm{OH}}\right)$ for SAPHIR experiments in 2010 under low-NO conditions (upper panels) and high-NO conditions (lower panels). Black and red data points indicate different periods of the experiments. Red: zero air period; Black: after the injection of aromatics. The solid lines correspond to the mean ratios listed in the third column of Table 3 ( $P_{\mathrm{OH}}$ calculated by Eq. 2), dashed lines are $1: 1$ lines.

afternoon hours, respectively (Hofzumahaus et al., 2009). While in the field campaign a strong mismatch between $\mathrm{OH}$ production and destruction rates by a factor of three was obtained for low-NO conditions, only an insignificant difference was observed here as discussed above. This clearly shows that the presence of aromatic compounds plays no role for the explanation of these field observations.

\section{Conclusions}

$\mathrm{OH}$ production and destruction rates, exclusively calculated from measured quantities, were determined for the first time during SAPHIR atmosphere simulation chamber experiments with the aromatic hydrocarbons benzene, toluene, $p$-xylene and 1,3,5-trimethylbenzene. A widely model-independent, steady-state approach for $\mathrm{OH}$ was used for an $\mathrm{OH}$ budget determination. Considering primary $\mathrm{OH}$ production and recycling reactions by photolysis and $\mathrm{HO}_{2}+\mathrm{NO}$, measured $\mathrm{OH}$ destruction rates slightly exceeded $\mathrm{OH}$ production rates by factors ranging between 1.1 and 1.6 under low-NO conditions $(0.1-0.2 \mathrm{ppb}$ of $\mathrm{NO})$ and 0.9 1.2 under high-NO conditions (7-8 ppb of NO). $\mathrm{CO}$ reference experiments show that the $\mathrm{OH}$ budgets were balanced within the accuracy of this analysis. Further $\mathrm{OH}$ production in $\mathrm{HO}_{2}+\mathrm{RO}_{2}$ reactions that have recently been proposed in the literature may be operative but turned out to be insignificant within experimental error under the conditions of this work. 


\section{Appendix A: Correction of $\mathrm{HO}_{2}$ measurement interferences}

The LIF technique can only detect $\mathrm{OH}$ radicals. Measurements of $\mathrm{HO}_{2}$ and $\mathrm{RO}_{2}$ radicals by LIF work via conversion to $\mathrm{OH}$ upon addition of $\mathrm{NO}$. The $\mathrm{HO}_{2}$-to- $\mathrm{OH}$ conversion is direct and can be made shortly before the excitation of $\mathrm{OH}$ within the expansion of the sample gas (Holland et al., 2003). In contrast, $\mathrm{RO}_{2}$ has to be converted to $\mathrm{HO}_{2}$ first which requires at least one additional $\mathrm{O}_{2}$ reaction following the $\mathrm{RO}_{2}+\mathrm{NO}$ reaction. This $\mathrm{RO}_{2}$-to- $\mathrm{HO}_{2}$ conversion is accomplished in a pre-reactor (Fuchs et al., 2008). The different reaction times thus allow a distinction between $\mathrm{OH}$ from $\mathrm{HO}_{2}$ and $\mathrm{RO}_{2}$. However, dependent on the nature of the $\mathrm{RO}_{2} \mathrm{rad}-$ icals this distinction is not complete because some $\mathrm{RO}_{2}$ produce $\mathrm{HO}_{2}$ too rapidly. Therefore, LIF $\mathrm{HO}_{2}$ measurements, $\left[\mathrm{HO}_{2}^{*}\right]$, have to be corrected for the concentration of a number of interfering $\mathrm{RO}_{2}$ radicals, $\left[\mathrm{RO}_{2}\right]_{i}$, detected with the corresponding relative sensitivities $\alpha_{\mathrm{RO}_{2}}^{i}$ to obtain the true $\mathrm{HO}_{2}$ concentration, $\left[\mathrm{HO}_{2}\right]$ (Fuchs et al., 2011; Lu et al., 2012).

$\left[\mathrm{HO}_{2}\right]=\left[\mathrm{HO}_{2}^{*}\right]-\sum_{i} \alpha_{\mathrm{RO}_{2}}^{i}\left[\mathrm{RO}_{2}\right]_{i}$

Accordingly, the true $\mathrm{RO}_{2}$ concentration (excluding $\mathrm{RO}_{2}$ that form no $\mathrm{HO}_{2}$ at all), $\left[\mathrm{RO}_{2}\right]$, is given by the sum of the $\mathrm{RO}_{2}$ concentration measured by LIF, $\left[\mathrm{RO}_{2}^{*}\right]$, plus the contribution of those $\mathrm{RO}_{2}$ radicals, $\alpha_{\mathrm{RO}_{2}}^{i} \times\left[\mathrm{RO}_{2}\right]_{i}$, that were spuriously detected as $\mathrm{HO}_{2}$.

$\left[\mathrm{RO}_{2}\right]=\left[\mathrm{RO}_{2}^{*}\right]+\sum_{i} \alpha_{\mathrm{RO}_{2}}^{i}\left[\mathrm{RO}_{2}\right]_{i}$

For peroxy radicals formed secondarily following the $\mathrm{OH}+$ benzene reaction, relative detection sensitivities compared to that for $\mathrm{HO}_{2}$ of $\alpha_{\mathrm{RO}_{2}}^{\text {benzene }}=0.86$ were determined experimentally in 2010. In 2011, $\alpha_{\mathrm{RO}_{2}}^{\text {benzene }}$ was then reduced to 0.17 by means of technical changes of the experimental setup (Fuchs et al., 2011).

Speciated $\mathrm{RO}_{2}$ measurements were not available and consequently, the correction of the LIF data was made on the basis of numerical MCMv3.2 simulations. More details on these simulations are given elsewhere (Nehr et al., 2014). Individual organic peroxy radical concentrations, $\left[\mathrm{RO}_{2}\right]_{i}$, were calculated for each SAPHIR experiment. Organic peroxy radicals involved in the photo-oxidation of aromatics and detectable by LIF are listed in Table A1. $\alpha_{\mathrm{RO}_{2}}^{\text {benzene was used }}$ for the corrections according to Eqs. (A1) and (A2) for all $\left[\mathrm{RO}_{2}\right]_{i}$. Additional MCMv3.2 based factors $c_{\mathrm{RO}}^{i}$ and $c_{\mathrm{HO}_{2}}^{i}$ that account for the yields of RO in Reaction (R7) and the yields of $\mathrm{HO}_{2}$ in Reaction (R8), respectively were also considered. Regarding the $P_{\mathrm{OH}}-D_{\mathrm{OH}}$ relationships the corrections of $\mathrm{HO}_{2}$ concentrations finally led to ratios $D_{\mathrm{OH}} / P_{\mathrm{OH}}$ that were greater by $0.17 \pm 0.12$ for the 2010 data and by $0.05 \pm 0.03$ for the 2011 data.
Table A1. Organic peroxy radicals (MCM specific designation) detectable but not discriminable by LIF and their respective RO yields $\left(c_{\mathrm{RO}}\right)$ in $\mathrm{RO}_{2}+\mathrm{NO}$ reactions and subsequent $\mathrm{HO}_{2}$ yields $\left(c_{\mathrm{HO}_{2}}\right)$ in $\mathrm{RO}+\mathrm{O}_{2}$ reactions as implemented in MCMv3.2.

\begin{tabular}{|c|c|c|c|c|c|c|}
\hline $\mathrm{RO}_{2}$ species & 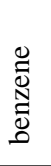 & $\begin{array}{l}\stackrel{0}{0} \\
\stackrel{0}{0}\end{array}$ & 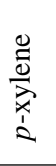 & $\begin{array}{l}\sum_{i}^{n} \\
\stackrel{n}{1} \\
\stackrel{n}{-}\end{array}$ & $c_{\mathrm{RO}}$ & $c_{\mathrm{HO}_{2}}$ \\
\hline BZBIPERO2 & $x$ & & & & 0.92 & 1.00 \\
\hline BZEMUCO2 & $\times$ & & & & 0.90 & 0.50 \\
\hline C5DIALO2 & $x$ & & & & 1.00 & 1.00 \\
\hline PHENO2 & $x$ & & & & 1.00 & 1.00 \\
\hline $\mathrm{HCOCO} 3$ & $\times$ & $x$ & $x$ & $x$ & 1.00 & 1.00 \\
\hline $\mathrm{HOCH} 2 \mathrm{CO} 3$ & $\times$ & $x$ & $x$ & $x$ & 1.00 & 1.00 \\
\hline MALDIALCO3 & $\times$ & $x$ & & & 1.00 & 1.00 \\
\hline C3DIALO2 & $\times$ & $x$ & & & 1.00 & 1.00 \\
\hline MALDIALO2 & $\times$ & $x$ & & & 1.00 & 1.00 \\
\hline NBZFUO2 & $x$ & $x$ & & & 1.00 & 0.50 \\
\hline BZFUO2 & $\times$ & $x$ & & & 1.00 & 1.00 \\
\hline HCOCOHCO3 & $x$ & $x$ & $x$ & & 1.00 & 1.00 \\
\hline NCATECO2 & $x$ & & & & 1.00 & 1.00 \\
\hline $\mathrm{C} 5 \mathrm{CO} 2 \mathrm{OHCO} 3$ & $\times$ & & & & 1.00 & 1.00 \\
\hline $\mathrm{C} 4 \mathrm{CO} 2 \mathrm{DBCO} 3$ & $\times$ & & & & 1.00 & 1.00 \\
\hline C6H5CH2O2 & & $x$ & & & 0.90 & 1.00 \\
\hline TLBIPERO2 & & $x$ & & & 0.89 & 1.00 \\
\hline CRESO2 & & $x$ & & & 1.00 & 1.00 \\
\hline TLEMUCO2 & & $x$ & & & 0.90 & 0.50 \\
\hline $\mathrm{C} 615 \mathrm{CO} 2 \mathrm{O} 2$ & & $x$ & & & 1.00 & 1.00 \\
\hline $\mathrm{C} 5 \mathrm{CO} 14 \mathrm{O} 2$ & & $x$ & $x$ & & 1.00 & 0.17 \\
\hline C3MCODBCO3 & & $x$ & $\times$ & & 1.00 & 1.00 \\
\hline MC3CODBCO3 & & $x$ & $x$ & & 1.00 & 0.65 \\
\hline C4M2ALOHO2 & & $x$ & $x$ & & 1.00 & 1.00 \\
\hline C5DICARBO2 & & $x$ & & & 1.00 & 1.00 \\
\hline TLFUO2 & & $x$ & & & 1.00 & 1.00 \\
\hline MNCATECO2 & & $x$ & & & 1.00 & 1.00 \\
\hline PXYFUO2 & & $x$ & & & 1.00 & 1.00 \\
\hline $\mathrm{CO} 2 \mathrm{H} 3 \mathrm{CO} 3$ & & $x$ & $x$ & $x$ & 1.00 & 1.00 \\
\hline C6CO2OHCO3 & & $x$ & & & 1.00 & 1.00 \\
\hline PXYLO2 & & & $x$ & & 0.90 & 1.00 \\
\hline PXYBIPERO2 & & & $x$ & & 0.86 & 1.00 \\
\hline PXYMUCO2 & & & $x$ & & 0.83 & 0.50 \\
\hline C6M5CO2O2 & & & $x$ & & 1.00 & 1.00 \\
\hline PXYOLO2 & & & $x$ & & 1.00 & 1.00 \\
\hline C3MDIALO2 & & & $\times$ & $x$ & 1.00 & 1.00 \\
\hline DMKOHO2 & & & $x$ & & 1.00 & 0.30 \\
\hline PXYFUO2 & & & $\times$ & & 1.00 & 1.00 \\
\hline $\mathrm{C} 4 \mathrm{CO} 2 \mathrm{O} 2$ & & & $x$ & & 1.00 & 0.50 \\
\hline СHOMOHCO3 & & & $x$ & $\times$ & 1.00 & 1.00 \\
\hline PXNCATECO2 & & & $x$ & & 1.00 & 1.00 \\
\hline TL4OHNO2O2 & & & $x$ & & 1.00 & 1.00 \\
\hline С6MOHCOCO3 & & & $\times$ & & 1.00 & 1.00 \\
\hline C5DBCO2CO3 & & & $x$ & & 1.00 & 1.00 \\
\hline TMBO2 & & & & $x$ & 0.90 & 1.00 \\
\hline TM135BPRO2 & & & & $x$ & 0.84 & 1.00 \\
\hline TM135OLO2 & & & & $\times$ & 1.00 & 1.00 \\
\hline TM135MUCO2 & & & & $\times$ & 0.94 & 0.50 \\
\hline $\mathrm{C} 5 \mathrm{MCO} 2 \mathrm{OHO} 2$ & & & & $x$ & 1.00 & 1.00 \\
\hline MXYFUO2 & & & & $\times$ & 1.00 & 1.00 \\
\hline C4COMOHCO3 & & & & $x$ & 1.00 & 1.00 \\
\hline
\end{tabular}


Acknowledgements. The authors cordially thank M. Bachner, F. Holland, K. D. Lu, P. Müsgen, and M. Vietz for additional measurements and technical support. B. Bohn and S. Nehr thank the Deutsche Forschungsgemeinschaft for funding under grant BO 1580/3-1.

The service charges for this open access publication have been covered by a Research Centre of the Helmholtz Association.

Edited by: M. Kulmala

\section{References}

Arneth, A., Schurgers, G., Lathiere, J., Duhl, T., Beerling, D. J., Hewitt, C. N., Martin, M., and Guenther, A.: Global terrestrial isoprene emission models: sensitivity to variability in climate and vegetation, Atmos. Chem. Phys., 11, 8037-8052, doi:10.5194/acp-11-8037-2011, 2011.

Birdsall, A. W. and Elrod, M. J.: Comprehensive NO-dependent study of the products of the oxidation of atmospherically relevant aromatic compounds, J. Phys. Chem. A, 115, 5397-5407, doi:10.1021/jp2010327, 2011.

Birdsall, A. W., Andreoni, J. F., and Elrod, M. J.: Investigation of the role of bicyclic peroxy radicals in the oxidation mechanism of toluene, J. Phys. Chem. A, 114, 10655-10663, doi:10.1021/jp105467e, 2010.

Bloss, C., Wagner, V., Bonzanini, A., Jenkin, M. E., Wirtz, K., Martin-Reviejo, M., and Pilling, M. J.: Evaluation of detailed aromatic mechanisms (MCMv3 and MCMv3.1) against environmental chamber data, Atmos. Chem. Phys., 5, 623-639, doi:10.5194/acp-5-623-2005, 2005a.

Bloss, C., Wagner, V., Jenkin, M. E., Volkamer, R., Bloss, W. J., Lee, J. D., Heard, D. E., Wirtz, K., Martin-Reviejo, M., Rea, G., Wenger, J. C., and Pilling, M. J.: Development of a detailed chemical mechanism (MCMv3.1) for the atmospheric oxidation of aromatic hydrocarbons, Atmos. Chem. Phys., 5, 641-664, doi:10.5194/acp-5-641-2005, 2005b.

Bohn, B. and Zilken, H.: Model-aided radiometric determination of photolysis frequencies in a sunlit atmosphere simulation chamber, Atmos. Chem. Phys., 5, 191-206, doi:10.5194/acp-5-1912005, 2005.

Calpini, B., Jeanneret, F., Bourqui, M., Clappier, A., Vajtai, R., and van den Bergh, H.: Direct measurement of the total reaction rate of $\mathrm{OH}$ in the atmosphere, Analusis, 27, 328-336, doi:10.1051/analusis:1999270328, 1999.

Calvert, J. G., Atkinson, R., Becker, K.-H., Kamens, R. M., Seinfeld, J. H., Wallington, T. J., and Yarwood, G.: Mechanisms of atmospheric oxidation of aromatic hydrocarbons, Oxford University Press, New York, USA, 2002.

Crounse, J. D., Paulot, F., Kjaergaard, H. G., and Wennberg, P. O.: Peroxy radical isomerization in the oxidation of isoprene, Phys. Chem. Chem. Phys., 13, 13607-13613, doi:10.1039/C1CP21330J, 2011.

Dillon, T. J. and Crowley, J. N.: Direct detection of OH formation in the reactions of $\mathrm{HO}_{2}$ with $\mathrm{CH}_{3} \mathrm{C}(\mathrm{O}) \mathrm{O}_{2}$ and other substituted peroxy radicals, Atmos. Chem. Phys., 8, 4877-4889, doi:10.5194/acp-8-4877-2008, 2008.
Dorn, H., Brandenburger, U., Brauers, T., and Hausmann, H.: A new in-situ laser long-path absorption instrument for the measurement of tropospheric OH radicals, J. Atmos. Sci., 52, 3373 3380, 1995.

Dorn, H.-P., Apodaca, R. L., Ball, S. M., Brauers, T., Brown, S. S., Crowley, J. N., Dubé, W. P., Fuchs, H., Häseler, R., Heitmann, U., Jones, R. L., Kiendler-Scharr, A., Labazan, I., Langridge, J. M., Meinen, J., Mentel, T. F., Platt, U., Pöhler, D., Rohrer, F., Ruth, A. A., Schlosser, E., Schuster, G., Shillings, A. J. L., Simpson, W. R., Thieser, J., Tillmann, R., Varma, R., Venables, D. S., and Wahner, A.: Intercomparison of $\mathrm{NO}_{3}$ radical detection instruments in the atmosphere simulation chamber SAPHIR, Atmos. Meas. Tech., 6, 1111-1140, doi:10.5194/amt-6-1111-2013, 2013.

Ehhalt, D. H.: Photooxidation of trace gases in the troposphere, Phys. Chem. Chem. Phys., 1, 5401-5408, doi:10.1039/A905097C, 1999.

Finlayson-Pitts, B. J. and Pitts, J. N.: Chemistry of the upper and lower atmosphere: Theory, experiments, and applications, Academic Press, San Diego, USA, 2000.

Fortin, T. J., Howard, B. J., Parrish, D. D., Goldan, P. D., Kuster, W. C., Atlas, E. L., and Harley, R. A.: Temporal changes in US benzene emissions inferred from atmospheric measurements, Environ. Sci. Technol., 39, 1403-1408, doi:10.1021/es049316n, 2005.

Fuchs, H., Holland, F., and Hofzumahaus, A.: Measurement of tropospheric $\mathrm{RO}_{2}$ and $\mathrm{HO}_{2}$ radicals by a laser-induced fluorescence instrument, Rev. Sci. Instrum., 79, 84-104, doi:10.1063/1.2968712, 2008.

Fuchs, H., Ball, S. M., Bohn, B., Brauers, T., Cohen, R. C., Dorn, H.-P., Dube, W. P., Fry, J. L., Häseler, R., Heitmann, U., Jones, R. L., Kleffmann, J., Mentel, T. F., Müsgen, P., Rohrer, F., Rollins, A. W., Ruth, A. A., Kiendler-Scharr, A., Schlosser, E., Shillings, A. J. L., Tillmann, R., Varma, R. M., Venables, D. S., Tapia, G. V., Wahner, A., Wegener, R., Wooldridge, P. J., and Brown, S. S.: Intercomparison of measurements of $\mathrm{NO}_{2}$ concentrations in the atmosphere simulation chamber SAPHIR during the NO3Comp campaign, Atmos. Meas. Tech., 3, 21-37, doi:10.5194/amt-3-21-2010, 2010.

Fuchs, H., Bohn, B., Hofzumahaus, A., Holland, F., Lu, K., Nehr, S., Rohrer, F., and Wahner, A.: Detection of $\mathrm{HO}_{2}$ by laser-induced fluorescence: calibration and interferences from $\mathrm{RO}_{2}$ radicals, Atmos. Meas. Tech., 4, 1209-1225, doi:10.5194/amt-4-12092011, 2011.

Fuchs, H., Dorn, H.-P., Bachner, M., Bohn, B., Brauers, T., Gomm, S., Hofzumahaus, A., Holland, F., Nehr, S., Rohrer, F., Tillmann, R., and Wahner, A.: Comparison of $\mathrm{OH}$ concentration measurements by DOAS and LIF during SAPHIR chamber experiments at high $\mathrm{OH}$ reactivity and low NO concentration, Atmos. Meas. Tech., 5, 1611-1626, doi:10.5194/amt-5-1611-2012, 2012.

Fuchs, H., Hofzumahaus, A., Rohrer, F., Bohn, B., Brauers, T., Dorn, H.-P., Haeseler, R., Holland, F., Kaminski, M., Li, X., Lu, K., Nehr, S., Tillmann, R., Wegener, R., and Wahner, A.: Experimental evidence for efficient hydroxyl radical regeneration in isoprene oxidation, Nat. Geosci., 6, 1023-1026, doi:10.1038/NGEO1964, 2013.

Groß, C. B. M., Dillon, T. J., Schuster, G., Lelieveld, J., and Crowley, J. N.: Direct kinetic study of $\mathrm{OH}$ and $\mathrm{O}_{3}$ formation in the 
reaction of $\mathrm{CH}_{3} \mathrm{C}(\mathrm{O}) \mathrm{O}_{2}$ with $\mathrm{HO}_{2}$, J. Phys. Chem. A, 118, 974985, doi:10.1021/jp412380z, 2014.

Hasson, A. S., Tyndall, G. S., and Orlando, J. J.: A product yield study of the reaction of $\mathrm{HO}_{2}$ radicals with ethyl peroxy $\left(\mathrm{C}_{2} \mathrm{H}_{5} \mathrm{O}_{2}\right)$, acetyl peroxy $\left(\mathrm{CH}_{3} \mathrm{C}(\mathrm{O}) \mathrm{O}_{2}\right)$, and acetonyl peroxy $\left(\mathrm{CH}_{3} \mathrm{C}(\mathrm{O}) \mathrm{CH}_{2} \mathrm{O}_{2}\right)$ radicals, J. Phys. Chem. A, 108, 5979-5989, doi:10.1021/jp048873t, 2004.

Hasson, A. S., Tyndall, G. S., Orlando, J. J., Singh, S., Hernandez, S. Q., Campbell, S., and Ibarra, Y.: Branching ratios for the reaction of selected carbonyl-containing peroxy radicals with hydroperoxy radicals, J. Phys. Chem. A, 116, 6264-6281, doi:10.1021/jp211799c, 2012.

Hawthorne, S., Miller, D., Barkley, R., and Krieger, M.: Identification of methoxylated phenols as candidate tracers for atmospheric wood smoke pollution, Environ. Sci. Technol., 22, 11911196, 1988

Hofzumahaus, A., Rohrer, F., Lu, K., Bohn, B., Brauers, T., Chang, C.-C., Fuchs, H., Holland, F., Kita, K., Kondo, Y., Li, X., Lou, S., Shao, M., Zeng, L., Wahner, A., and Zhang, Y.: Amplified trace gas removal in the troposphere, Science, 324, 1702-1704, doi:10.1126/science.1164566, 2009.

Holland, F., Hofzumahaus, A., Schäfer, R., Kraus, A., and Pätz, H.-W.: Measurements of $\mathrm{OH}$ and $\mathrm{HO}_{2}$ radical concentrations and photolysis frequencies during BERLIOZ, J. Geophys. Res.Atmos., 108, 8246-8268, doi:10.1029/2001JD001393, 2003.

IUPAC: Subcommittee for Gas Kinetic Data Evaluation, available at: http://iupac.pole-ether.fr/ (last access: 11 October 2013), 2013.

Jenkin, M. E.: Interactive comment on "Atmospheric photochemistry of aromatic hydrocarbons: $\mathrm{OH}$ budgets during SAPHIR chamber experiments" by S. Nehr et al., Atmos. Chem. Phys. Discuss., 14, C1058-C1058, 2014.

Jenkin, M. E., Hurley, M. D., and Wallington, T. J.: Investigation of the radical product channel of the $\mathrm{CH}_{3} \mathrm{C}(\mathrm{O}) \mathrm{O}_{2}+\mathrm{HO}_{2}$ reaction in the gas phase, Phys. Chem. Chem. Phys., 9, 3149-3162, doi:10.1039/B702757E, 2007.

Jenkin, M. E., Hurley, M. D., and Wallington, T. J.: Investigation of the radical product channel of the $\mathrm{CH}_{3} \mathrm{C}(\mathrm{O}) \mathrm{CH}_{2} \mathrm{O}_{2}+\mathrm{HO}_{2}$ reaction in the gas phase, Phys. Chem. Chem. Phys., 10, 4274-4280, doi:10.1039/b802898b, 2008.

Jenkin, M. E., Hurley, M. A., and Wallington, T. J.: Investigation of the radical product channel of the $\mathrm{CH}_{3} \mathrm{OCH}_{2} \mathrm{O}_{2}+\mathrm{HO}_{2}$ Reaction in the Gas Phase, J. Phys. Chem. A, 114, 408-416, doi:10.1021/jp908158w, 2010.

Johnson, M. M., Williams, R., Fan, Z., Lin, L., Hudgens, E., Gallagher, J., Vette, A., Neas, L., and Ozkaynak, H.: Participantbased monitoring of indoor and outdoor nitrogen dioxide, volatile organic compounds, and polycyclic aromatic hydrocarbons among MICA-Air households, Atmos. Environ., 44, 49274936, doi:10.1016/j.atmosenv.2010.08.027, 2010.

Karl, M., Brauers, T., Dorn, H.-P., Holland, F., Komenda, M., Poppe, D., Rohrer, F., Rupp, L., Schaub, A., and Wahner, A.: Kinetic Study of the $\mathrm{OH}$-isoprene and $\mathrm{O}_{3}$-isoprene reaction in the atmosphere simulation chamber, SAPHIR, Geophys. Res. Lett., 31, L05117, doi:10.1029/2003GL019189, 2004.

Kleffmann, J.: Daytime sources of nitrous acid (HONO) in the atmospheric boundary layer, Chem. Phys. Phys. Chem. , 8, 11371144, doi:10.1002/cphc.200700016, 2007.
Lelieveld, J., Butler, T. M., Crowley, J. N., Dillon, T. J., Fischer, H., Ganzeveld, L., Harder, H., Lawrence, M. G., Martinez, M., Taraborrelli, D., and Williams, J.: Atmospheric oxidation capacity sustained by a tropical forest, Nature, 452, 737-740, doi:10.1038/nature06870, 2008.

Lou, S., Holland, F., Rohrer, F., Lu, K., Bohn, B., Brauers, T., Chang, C., Fuchs, H., Häseler, R., Kita, K., Kondo, Y., Li, X., Shao, M., Zeng, L., Wahner, A., Zhang, Y., Wang, W., and Hofzumahaus, A.: Atmospheric $\mathrm{OH}$ reactivities in the Pearl River Delta - China in summer 2006: measurement and model results, Atmos. Chem. Phys., 10, 11243-11260, doi:10.5194/acp-10-11243-2010, 2010.

Lu, K. D., Rohrer, F., Holland, F., Fuchs, H., Bohn, B., Brauers, T., Chang, C. C., Häseler, R., Hu, L., Kita, K., Kondo, Y., Li, X., Lou, S. R., Nehr, S., Shao, M., Zeng, L. M., Wahner, A., Zhang, Y. H., and Hofzumahaus, A.: Observation and modelling of $\mathrm{OH}$ and $\mathrm{HO}_{2}$ concentrations in the Pearl River Delta 2006: a missing $\mathrm{OH}$ source in a VOC rich atmosphere, Atmos. Chem. Phys., 12, 1541-1569, doi:10.5194/acp-12-1541-2012, 2012.

Nehr, S., Bohn, B., Fuchs, H., Hofzumahaus, A., and Wahner, A.: $\mathrm{HO}_{2}$ formation from the $\mathrm{OH}$ plus benzene reaction in the presence of $\mathrm{O}_{2}$, Phys. Chem. Chem. Phys., 13, 10699-10708, doi:10.1039/C1CP20334G, 2011.

Nehr, S., Bohn, B., and Wahner, A.: Prompt $\mathrm{HO}_{2}$ formation following the reaction of $\mathrm{OH}$ with aromatic compounds under atmospheric conditions, J. Phys. Chem. A, 116, 6015-6026, doi:10.1021/jp210946y, 2012.

Nehr, S., Bohn, B., Brauers, T., Dorn, H.-P., Fuchs, H., Häseler, R., Hofzumahaus, A., Li, X., Lu, K. D., Rohrer, F., Tillmann, R., and Wahner, A.: Atmospheric photochemistry of aromatic hydrocarbons: Validation of MCMv3.2 against SAPHIR chamber data, Atmos. Chem. Phys. Discuss., in preparation, 2014.

Niedojadlo, A., Becker, K.-H., Kurtenbach, R., and Wiesen, P.: The contribution of traffic and solvent use to the total NMVOC emission in a German city derived from measurements and CMB modelling, Atmos. Environ., 41, 7108-7126, doi:10.1016/j.atmosenv.2007.04.056, 2007.

Peeters, J., Nguyen, T. L., and Vereecken, L.: $\mathrm{HO}_{\mathrm{x}}$ radical regeneration in the oxidation of isoprene, Phys. Chem. Chem. Phys., 11, 5935-5939, doi:10.1039/B908511D, 2009.

Piccot, S. D., Watson, J. J., and Jones, J. W.: A global inventory of volatile organic compound emissions from anthropogenic sources, J. Geophys. Res.-Atmos., 97, 9897-9912, doi:10.1029/92JD00682, 1992.

Poppe, D., Brauers, T., Dorn, H.-P., Karl, M., Mentel, T. F., Schlosser, E., Tillmann, R., Wegener, R., and Wahner, A.: OHinitiated degradation of several hydrocarbons in the atmosphere simulation chamber SAPHIR, J. Atmos. Chem., 57, 203-214, doi:10.1007/s10874-007-9065-y, 2007.

Rohrer, F., Bohn, B., Brauers, T., Brüning, D., Johnen, F. J., Wahner, A., and Kleffmann, J.: Characterisation of the photolytic HONO-source in the atmosphere simulation chamber SAPHIR, Atmos. Chem. Phys., 5, 2189-2201, doi:10.5194/acp-5-21892005, 2005.

Sadanaga, Y., Yoshino, A., Watanabe, K., Yoshioka, A., Wakazono, Y., Kanaya, Y., and Kajii, Y.: Development of a measurement system of $\mathrm{OH}$ reactivity in the atmosphere by using a laserinduced pump and probe technique, Rev. Sci. Instrum., 75, 2648 2655, doi:10.1063/1.1775311, 2004. 
Schlosser, E., Bohn, B., Brauers, T., Dorn, H.-P., Fuchs, H., Häseler, R., Hofzumahaus, A., Holland, F., Rohrer, F., Rupp, L. O., Siese, M., Tillmann, R., and Wahner, A.: Intercomparison of two hydroxyl radical measurement techniques at the atmosphere simulation chamber SAPHIR, J. Atmos. Chem., 56, 187-205, doi:10.1007/s10874-006-9049-3, 2007.

Schlosser, E., Brauers, T., Dorn, H. P., Fuchs, H., Häseler, R., Hofzumahaus, A., Holland, F., Wahner, A., Kanaya, Y., Kajii, Y., Miyamoto, K., Nishida, S., Watanabe, K., Yoshino, A., Kubistin, D., Martinez, M., Rudolf, M., Harder, H., Berresheim, H., Elste, T., Plass-Dülmer, C., Stange, G., and Schurath, U.: Technical Note: Formal blind intercomparison of $\mathrm{OH}$ measurements: results from the international campaign HOxComp, Atmos. Chem. Phys., 9, 7923-7948, doi:10.5194/acp-9-7923-2009, 2009.
Wagner, V., Jenkin, M. E., Saunders, S. M., Stanton, J., Wirtz, K., and Pilling, M. J.: Modelling of the photooxidation of toluene: conceptual ideas for validating detailed mechanisms, Atmos. Chem. Phys., 3, 89-106, doi:10.5194/acp-3-89-2003, 2003.

Wegener, R., Brauers, T., Koppmann, R., Rodrigues-Bares, S., Rohrer, F., Tillmann, R., Wahner, A., Hansel, A., and Wisthaler, A.: Simulation chamber investigation of the reactions of ozone with short-chained alkenes, J. Geophys. Res.-Atmos., 112, D13301, doi:10.1029/2006JD007531, 2007.

Wolfe, G. M., Crounse, J. D., Parrish, J. D., St. Clair, J. M., Beaver, M. R., Paulot, F., Yoon, T. P., Wennberg, P. O., and Keutsch, F. N.: Photolysis, $\mathrm{OH}$ reactivity and ozone reactivity of a proxy for isoprene-derived hydroperoxyenals (HPALDs), Phys. Chem. Chem. Phys., 14, 7276-7286, doi:10.1039/C2CP40388A, 2012. 